\title{
Should an iBSc in Management be compulsory for all UK medical students?
}

This article was published in the following Dove Press journal:

Advances in Medical Education and Practice

19 May 2015

Number of times this article has been viewed

\section{Bharpoor Singh' \\ Natalie Ramjeeawon ${ }^{2}$ \\ Neil Shah' \\ Shawmian Singagireson' \\ 'Imperial College London, London, UK; ${ }^{2}$ University of Sheffield, \\ Sheffield, UK}

Correspondence: Bharpoor Singh Faculty of Medicine, Imperial College London, Exhibition Road,

London SW7 2AZ, UK

Tel +44 20758 95 I I I

Email bharpoor.singh10@imperial.ac.uk

\section{Dear editor}

The UK medical school system has traditionally offered an intercalated science degree (iBSc) to supplement their regular medical degree. However, in recent times with an increasing focus on leadership in the National Health Service (NHS), there has been a shift. More medical schools now offer the option to study an iBSc in Management.

I have just spent a year completing an iBSc in Management at Imperial College Business School. Throughout the year I became more and more immersed in our intricate health care system, which is only really apparent to health care professionals whilst on the job. My question to the General Medical Council is - should an iBSc in Management be compulsory for all UK medical students?

Efficiency in a hospital is a big topic and there is a fine line in managing the tradeoff between exceptional clinical health care and budget restraints. "The Nicholson Challenge" originally set a target of $£ 20$ billion savings for the NHS by 2015 through efficiency measures. I am sure numerous health care professionals will know of the challenge, but many will be unaware of exactly what efficiency saving in a hospital entails.

By 2020/2021 a $£ 30$ billion funding gap ${ }^{2}$ is expected to open up in the NHS, enough to bankrupt any private sector firm. Key reforms in productivity are desperately needed if this coveted health system is to remain free at point of use. Implementing these measures requires a clear vision ubiquitously present in a workforce.

A management degree is designed to expose the individual to the wider world of health care. A wider world in which business and clinical science come together to produce the end product: health. The World Health Organization defines health as a human right. Being a human right means that we should have access to "timely, acceptable, and affordable health care of appropriate quality". ${ }^{3}$ Given the way the NHS is heading, I think this basic human right could be violated if correct action is not taken.

I firmly believe a year studying management will produce a better-equipped workforce capable of delivering the reforms needed in the NHS.

\section{Disclosure}

The authors have no conflicts of interest to disclose. 


\section{References}

1. National Health Service. NHS Chief Executive's Annual Report for 2008/09. NHS; 2009. Available from: http://www.healthcare-today.co.uk/ doclibrary/documents/pdf/215_the_year_2008-09.pdf. Accessed April 21, 2015.

2. National Health Service England. The NHS Belongs to the People: A Call to Action. National Health Service England; 2013. Available from: http://www.england.nhs.uk/wp-content/uploads/2013/07/nhs-belongs. pdf. Accessed April 21, 2015.
3. World Health Organization [homepage on the Internet]. WHO | The Right To Health; 2013. Available from: http://www.who.int/mediacentre/ factsheets/fs323/en/. Accessed April 13, 2015.

Dove Medical Press encourages responsible, free and frank academic debate. The content of the Advances in Medical Education and Practice 'letters to the editor' section does not necessarily represent the views of Dove Medical Press, its officers, agents, employees, related entities or the Advances in Medical Education and Practice editors. While all reasonable steps have been taken to confirm the content of each letter, Dove Medical Press accepts no liability in respect of the content of any letter, nor is it responsible for the content and accuracy of any letter to the editor.

Advances in Medical Education and Practice

\section{Dovepress}

\section{Publish your work in this journal}

Advances in Medical Education and Practice is an international, peerreviewed, open access journal that aims to present and publish research on Medical Education covering medical, dental, nursing and allied health care professional education. The journal covers undergraduate education, postgraduate training and continuing medical education including emerging trends and innovative models linking education, research, and health care services. The manuscript management system is completely online and includes a very quick and fair peer-review system. Visit http://www.dovepress.com/testimonials.php to read real quotes from published authors.

Submit your manuscript here: http://www.dovepress.com/advances-in-medical-education-and-practice-journal 